Jurnal Konstruksi Hukum | ISSN: XXXX | E-ISSN: XXXX Vol. 1, No. 1, September 2020 Hal. 19-25|Available online at https://www.ejournal.warmadewa.ac.id/index.php/jukonhum DOI: https://doi.org/10.22225/jkh.1.1.2124.19-25

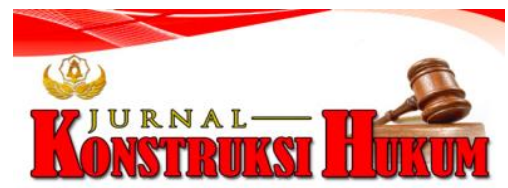

\title{
SANKSI PIDANA BAGI PELAKU TINDAK PIDANA PEDOFILIA TERHADAP ANAK
}

\author{
Agus Rai Mahardika, Anak Agung Sagung Laksmi Dewi, I Made Minggu Widyantara \\ Fakultas Hukum Universitas Warmadewa, Denpasar-Bali, Indonesia
}

\begin{abstract}
Abstrak
Di Indonesia, sampai saat ini, dunia anak semakin sangat memprihatinkan. Hal itu bukan hanya pernyataan semata tetapi fakta yang memang ada dan harus mendapatkan perhatian yang serius. Hal ini terbukti dengan semakin banyaknya pertumbuhan lembaga-lembaga swadaya masyarakat yang peduli dengan nasib anak Indonesia, dan ada itikad baik pemerintah untuk mengatasi keadaan tersebut dengan mengeluarkan peraturan yang lebih khusus untuk menjamin adanya perlindungan terhadap anak. Penelitian ini mengkaji pengaturan hukum bagi pelaku tindak pidana pelecehan seksual terhadap anak di bawah umur serta sanksi hukumnya. Penelitian ini merupakan penelitian hukum dan pendekatan yang digunakan adalah pendekatan yuridis normatif yang bersifat deskriptif analitik. Data yang dikumpulkan berasal dari peraturan perundang-undangan yang berlaku, yang dianalisis secara kuantitatif dan kemudian diinterprestasikan dengan metode deduktif. Pelecehan seksual adalah suatu bentuk tindakan atau percakapan seksual di mana seorang dewasa mencari kepuasan seksual dari seorang anak. Pelecehan seksual pada anak dapat mencakup kontak atau interaksi antara anak dan orang dewasa, di mana, anak tersebut dipergunakan untuk stimulasi seksual oleh pelaku atau orang lain yang berada dalam posisi memiliki kekuatan atau kendali atas korban, termasuk di dalamnya kontak fisik yang tidak pantas, membuat pornografi atau memperlihatkan alat vital/genital orang dewasa kepada anak. Sanksi atas pelecehan seksual diatur secara khusus dalam KUHP, yakni dalam Pasal 287, 290, 293, 294, dan 295. Sedangkan, menurut Undang-Undang Perlindungan Anak No. 23 Tahun 2002, diatur dalam pasal 78, 82 dan 88. Dalam semua pasal-pasal di atas, dijelaskan tentang ketentuan pidana dan jenis pidana yang diberikan kepada pelaku pelecehan seksual. Sanksi yang diberikan berupa sanksi pidana penjara dan denda.
\end{abstract}

Kata Kunci: Pelaku; Sanksi Pidana; Tindak pidana pedofilia

\begin{abstract}
In Indonesia, to date, the world of children has become very concerning. This is not in words, but there is a fact that does exist and should receive serious attention. This is evidenced by the growing number of nongovernmental organizations caring about the fate of Indonesian children, and there is good faith in the government to overcome the situation by issuing stricter rules and regulations to ensure the protection for children. This study examines the legal arrangements for perpetrators of criminal acts of sexual harassment against minors and the legal sanctions. This research is a legal research and the approach used is a normative juridical approach that is descriptive analytic. The data collected comes from the prevailing laws and regulations, which are analyzed quantitatively and then interpreted by deductive method. Sexual harassment appears as a form of sexual act or discourse in which an adult seeks sexual gratification with a minor. Sexual abuse of a child can include contact or interaction between a child and an adult, wherein the child is exploited for sexual stimulation by the offender or another person who is in a position of power or control over the victim, including inappropriate physical contact, making pornography or showing adult genitals to children. Sanctions for sexual harassment are strictly regulated in the Criminal Code, namely in Articles 287, 290, 293, 294, and 295. Meanwhile, according to the Child Protection Law no. 23 of 2002, it is regulated in articles 78, 82 and 88. In all of these articles, it is explained about the criminal provisions and the types of sanctions given to the perpetrators of the sexual harassment. The sanctions given are in the form of imprisonment and fines.
\end{abstract}

Keyword: Perpetrator; Criminal Sanctions; Pedophilia

\section{PENDAhULUAN}

Undang-Undang Dasar Negara Republik Indonesia Tahun 1945 memiliki tujuan untuk perjuangan bangsa Indonesia yaitu untuk mencapai masyarakat yang adil dan makmur, supaya tercipta kesejahteraan sosial yang merata dan menyeluruh bagi seluruh rakyat Indonesia. Pasal 2B Ayat (2) Undang-Undang Dasar Negara Republik Indonesia Tahun 1945 menyatakan "Setiap anak berhak atas 
kelangsungan hidup, tumbuh, dan berkembang serta berhak atas perlindungan dari kekerasan dan diskriminasi". Anak sebagai makhluk Tuhan Yang Maha Esa dan sebagai makhluk sosial sejak dalam kandungan, mempunyai hak untuk hidup dan merdeka serta mendapat perlindungan (Poerwadarminta, 2002). Oleh karena anak baik secara rohani maupun jasmani belum mempunyai kemampuan untuk berdiri sendiri, menjadi kewajiban bagi orang tua, keluarga, masyarakat, bangsa dan negara untuk melindungi, menjamin, memelihara dan mengamankan kepentingan anak tersebut.

Adanya masalah ekonomi dan sosial yang melanda Indonesia berdampak pada peningkatan skala dan kompleksitas yang dihadapi anak Indonesia. Hal ini ditandai dengan makin banyaknya anak yang mengalami perlakuan salah, eksploitasi, tindak kekerasan, perdagangan anak dan lain-lain. Faktanya menunjukkan berbagai pelanggaran terhadap hak anak di Indonesia terus terjadi, bahkan sampai bentuk-bentuk pelanggaran yang tidak dapat ditoleransi oleh akal sehat. Anak sangat rentan menjadi korban dari tindak pidana (Balai Pustaka Sosial RI, 2002). Dari kasus yang saat ini sangat marak terjadi, anak-anak adalah korban dari pelaku tindak pidana pedofilia. Kasus pelecehan seksual terhadap anak di bawah umur ini menjadi momok yang perlu ditanggulangi agar anak-anak di bawah umur tidak menjadi trauma psikis yang dapat mengganggu mental dan kepribadiannya.

Pedofilia sebagai gangguan atau kelainan jiwa pada seseorang untuk bertindak dengan menjadikan anak-anak sebagai instrumen atau sasaran dari tindakan itu. Umumnya bentuk tindakan itu berupa pelampiasan nafsu seksual. Tindakan pelecehan seksual ini begitu meresahkan karena yang menjadi korban adalah anak-anak. Pelecehan seksual ini menimbulkan trauma psikis yang tidak bisa disembuhkan dalam waktu singkat. Pasal-pasal KUHP mengenai Tindak Pidana yang masuk ke golongan kejahatan atau misdrijven selalu mengandung unsur kesalahan dari pihak pelaku tindak pidana, yaitu kesengajaan atau culpa (Prodjodikoro, 1989).

Dalam Undang-Undang Nomor 35 Tahun 2014 atas perubahan Undang-Undang Nomor 23 Tahun 2002 tentang Perlindungan Anak ditetapkan bahwa Perlindungan Anak adalah segala kegiatan untuk menjamin dan melindungi anak dan hak-haknya agar dapat hidup, tumbuh, berkembang dan berpartisipasi secara optimal sesuai dengan harkat dan martabat kemanusiaan, serta mendapat perlindungan dari kekerasan dan diskriminasi.

Kejahatan kesusilaan secara umum merupakan perbuatan atau tindakan melanggar kesusilaan atau immoral yang sengaja merusak kesopanan di muka umum atau orang lain tidak atas kemauan si korban, tetapi dengan paksaan dan melalui ancaman kekerasan. Pedofilia merupakan suatu bentuk patologi sosial. Pedofilia menjadi ancaman yang nyata atau potensial terhadap norma-norma sosial sehingga bisa mengancam berlangsungnya ketertiban sosial. Dengan demikian pedofilia dapat menjadi penghambat pembangunan nasional yang beraspek material-spiritual. Kasus tindak pidana pedofilia, yang juga merusak norma kesopanan, melanggar kesusilaan karena adanya kepuasan ketika melakukan hubungan seksual dengan anak-anak. Walaupun Undang-Undang sudah mengatur tentang tindak pidana tersebut, yakni dengan menggunakan Pasal 290 KUHP dan UU No. 35 Tahun 2014 jo. UU No. 23 Tahun 2002 tentang Perlindungan Anak, dalam realitanya, ternyata pasal-pasal tersebut sangat lemah, karena ternyata tidak menimbulkan efek jera bagi pelaku dan bagi orang lain, sehingga kasus ini masih sangat marak dan mengancam anak-anak (Suma, 2001).

Masalah ekonomi dan sosial yang melanda Indonesia berdampak pada peningkatan skala dan komplesitas masalah yang dihadapi anak Indonesia yang ditandai dengan makin banyaknya anak yang mengalami perlakuan salah, eksploitasi, tindak kekerasan, anak yang diperdagangkan, penelantaran, disamping anak-anak yang tinggal di daerah rawan konflik, rawan bencana serta anak yang berhadapan dengan hukum dan lain sebagainya. Dampak nyata yang berkaitan dengan memburuknya kondisi perekonomian dan krisis moneter adalah meningkatnya jumlah anak di Panti Sosial Asuhan Anak milik masyarakat lebih diperberat lagi dengan menurunnya pendapatan masyarakat yang merupakan salah satu sumber dana (Depsos, 2002).

Kasus yang pernah terjadi dan terungkap di Indonesia adalah kasus mantan diplomat Australia, William Stuart Brown, yakni kejahatan seksual yang dilakukan terhadap dua anak di Karangasem. Kasus tersebut oleh beberapa pihak dipandang sebagai langkah maju bagi penegakan hukum perlindungan anak di Indonesia. Terlepas dari penyesalan dan simpati atau kasus bunuh diri Brown di Lembaga Permasyarakatan Amlapura, sehari setelah keputusan vonis itu, ada beberapa pelajaran penting yang bisa diambil dari. Kasus itu menggambarkan bagaimana pedofilia dan kejahatan seksual terhadap anak dipahami masyarakat serta bagaimana perangkat hukum meresponnya. 
Beberapa polemik yang muncul selama persisdangan kasus Brown, seperti klaim tidak terjadi kasus pelanggaran Undang-Undang Perlindungan Anak (UUPA). Dalam kasus ini dengan klaim tidak terjadi kekerasan dan paksaan terhadap korban menunjukkan betapa pedofilia masih sering dikacaukan pengertiannya. Ada tidaknya unsur kekerasan fisik masih sering dijadikan kriteria untuk mengategorikan tindak pelecehan seksual terhadap anak sebagai bentuk kejahatan atau bukan. Anak akan menjadi lost generation dikarenakan orang tua yang tidak cakap dalam mendidik. Hal tersebut membuat mereka menjadi sumber daya yang tidak komptitif hingga sangat kecil kemungkinan bagi mereka untuk mampu bekerja pada sektor formal dan hal demikian pada akhirnya membuat atau menyeret mereka menyerbu sektor informal atau ilegal.

Ternyata hak asasi tidak pernah diberi melainkan harus disebut dengan suatu gerakan perlindungan hukum terhadap anak-anak, anti kekerasan terhadap anak dan mengambil kembali hak asasi anak-anak yang hilang. Gerakan perlindungan hukum terhadap anak harus digencarkan di tengah-tengah masyarakat. Sebagai suatu gerakan nasional di dalam upaya memberikan perlindungan hukum terhadap anak perlu melibatkan seluruh segmen yang ada. Seperti badan pemerintah, lembaga sosial masyarakat, organisasi sosial, aparat hukum, tokoh agama, dari kalangan pers serta lembagalembaga akademik dan para pakar-pakar untuk bersama-sama, bahu-membahu dalam mewujudkan anak Indonesia yang teguh imannya, berpendidikan, sehat dan tangguh dalam bersaing serta dapat menentukan masa depannya sendiri (Sholeh, 2001).

Perilaku seksual sangat bermacam-macam dan ditentukan oleh suatu interaksi faktor-faktor yang kompleks. Perilaku seksual dipengaruhi oleh hubungan seseorang dengan orang lain, oleh lingkungan sekitar dan kultur yang berkembang. Pedofilia merupakan salah satu kasus paraphilia yang sering terjadi di antara kasus-kasus paraphilia yang lain seperti: ekshibisionisme, fetihisme, frotteurisme, maukisme seksual (Sa'abah, 1997). Pedofilia adalah seseorang mendapatkan kepuasan seksnya dari hubungan seksual dengan anak-anak (Irianto, 2010).

Dilihat dari berbagai bentuk dan karakteristik, dalam perbuatan kaum pedofilia bisa dikatakan anak-anak dieksploitasi sebagai korban. Anak-anak sebagai korban mestinya dilindungi dan memperoleh pelayanan khusus, terutama di bidang hukum. Secara yuridis, pihak yang dituntut bertanggungjawab adalah ekploitatornya atau pelakunya. Selama ini Undang-Undang yang sering digunakan untuk mengadili penjahat ini adalah KUHP Pasal 292 juncto Pasal 64 tentang Pencabulan. Tuntutannya ialah maksimal 5 tahun dan ini dipandang, oleh banyak aktivis perlindungan anak, sudah tidak relevan untuk memberikan efek jera bagi si pelaku. Selain itu, dalam Pasal 287 KUHP disebutkan sanksi maksimal 9 tahun penjara. Namun dalam hal tidak ada pengaduan, penuntutan tidak akan dilakukan. Hal ini tentu menjadi titik lemah dalam KUHP tersebut, karena dalam realitanya, korban terkadang memang tidak melaporkan kejadian tersebut dengan berbagai alasan seperti ancaman dan rasa malu.

Dengan tidak adanya pengaturan sanksi pidana yang secara khusus mengatur tentang tindak pidana pedofilia ini dalam hukum Positif Indonesia tentu menjadi masalah. Dan masih banyak kasus yang lainnya. Oleh karena itu, penelitian ini dilakukan untuk menindak lanjuti pengkajian lebih lanjut.

Berdasarkan uraian kasus di atas, terdapat dua kasus hukum yang dikaji dalam penelitian ini:

1) Bagaimanakah pengaturan tindak pidana pedofilia terhadap anak?

2) Bagaimana sanksi pidana bagi pelaku tindak pidana pedofilia terhadap anak?

Secara umum penelitian ini dilakukan untuk mengungkap sanksi pidana terhadap tindak pidana pedofilia sesuai dengan peraturan perundang-undangan yang mengaturnya; sedangkan, secara khusus penelitian ini bertujuan untuk mengetahui pengaturan tentang tindak pidana pedofilia terhadap anak dan mengetahui sanksi bagi pelaku tindak pidana tersebut.

\section{METODE PENELITIAN}

Tipe penelitian yang digunakan dalam kajian ini adalah penelitian hukum normatif. Sesuai dengan tipe penelitian hukum yang digunakan, pendekatan masalah yang digunakan dalam penelitian ini adalah pendekatan yuridis normatif, suatu penelitian yang menekankan pada ilmu hukum dan yang berusaha menelaah kaidah-kaidah hukum yang berlaku dalam masyarakat, terutama untuk mengkaji ketentuan yang permasalahan yang diteliti. Pada penelitian ini dikaji aspek hukum yang berkaitan dengan analisis yuridis terhadap tindak pidana pedofilia. 
Sumber bahan hukum yang digunakan oleh penulis untuk menunjang hasil penelitian ini adalah: pertama, bahan hukum primer, yang diperoleh melalui studi kepustakaan. Studi kepustakaan adalah suatu bentuk penelitian yang dilakukan dengan mempelajari, mengkaji, menganalisis bahanbahan tertulis dan dilakukan untuk hal-hal yang sifatnya teoretis mengenai asas-asas, konsep-konsep, pandangan-pandangan dan doktrin-doktrin hukum yang meliputi: Pasal 290 KUHP dan UndangUndang Nomor 35 Tahun 2014 jo Undang-Undang Nomor 23 Tahun 2002 tentang Perlindungan Anak. Kedua, bahan hukum sekunder yang meliputi bahan hukum yang memberi penjelasan tentang bahan hukum primer dan berbentuk literatur-literatur, artikel jurnal-jurnal, buku-buku, artikel serta surat kabar. Ketiga, bahan hukum tersier, yaitu bahan-bahan yang memberikan informasi tentang bahan hukum primer dan bahan hukum sekunder, yang ada relevansinya dengan tindak pidana pedofilia. Bahan hukum tersier diperoleh dari seumber di luar hukum yang sedang dipergunakan untuk melengkapi atau menunjang data penelitian, seperti internet, situs website, kamus hukum dan ensiklopedia.

\section{HASIL DAN PEMBAHASAN}

\section{Pengaturan tentang Tindak Pidana Pedofilia terhadap Anak}

Pedofilia digolongkan sebagai kejahatan terhadap anak karena mengakibatkan dampak buruk bagi korban. Menurut ahli kejiwaan anak yang kini menjadi Ketua Komisi Nasional Perlindungan Anak (Komnas Anak) Seto Mulyadi, para korban pedofilia akan mengalami gejala kehilangan rasa percaya diri dan memiliki pandangan negatif terhadap seks. Para pedofilia memiliki kecendrungan untuk melakukan hubungan seksual dengan anak-anak, baik anak laki-laki di bawah umur (pedofilia homoseksual) ataupun dengan anak perempuan di bawah umur (pedofilia heteroseksual) (Sadarjoen, 2005)

Berdasarkan kenyataan tersebut, kejahatan anak, khususnya kejahatan seksual pada anak (pedofilia) harus ditanggulangi dengan hukum pidana. Kebijakan hukum pidana dalam rangka melindungi anak dari objek kejahatan sudah diterapkan dalam KUHP. Di dalam KUHP terdapat ketentuan tentang larangan melakukan persetubuhan dengan wanita di luar perkawinan dan belum berusia lima belas tahun (Pasal 287); larangan melakukan perbuatan cabul bagi orang dewasa dengan orang lain sesama jenis kelamin dan belum dewasa (Pasal 292) (Marpaung, 1996).

Pengertian tindak pidana dalam Kitab Undang-Undang Hukum Pidana (KUHP) dikenal dengan istilah stratbaar feit dan dalam kepustakaan tentang hukum pidana sering diistilahkan dengan delik, sedangkan pembuat undang-undang merumuskannya melalui suatu undang-undang dengan mempergunakan istilah peristiwa pidana atau perbuatan pidana atau tindak pidana. Tindak pidana merupakan suatu dasar yang pokok dalam menjatuhi pidana pada orang yang telah melakukan perbuatan pidana atas dasar pertanggung jawaban seseorang atau perbuatan yang telah dilakukannya, tapi sebelum ini mengenai dilarang dan diancamnya suatu perbuatan yaitu mengenai perbuatan pidananya sendiri, yaitu berdasarkan azas legalitas (Principle of legality), asas yang menentukan bahwa tidak ada perubahan yang dilarang dan diancam dengan pidana jika tidak ditentukan terlebih dahulu dalam perundang-undangan (Kartonegero, 2012).

Jika dicermati lebih jauh, kejahatan pedofilia ini tergolong dalam kejahatan terhadap kesusilaan. Makna kesusilaan ini harus diartikan sebagai hal-hal yang termasuk dalam penguasaan norma-norma kepatutan bertingkah laku dalam pergaulan masyarakat tidak hanya berkaitan dengan pengertian kesusilaan dalam bidang seksual (Tongat, 2003). Menentukan materinya atau subtansinya harus bersumber dan mendapat sandaran kuat dari moral agama (Arief, 2002). Senada dengan pendapat tersebut, Kusuma menyatakan kejahatan seks serta kejahatan yang menyangkut seks (sexrelated crimes) yang dirumuskan dalam hukum pidana sebagai delik susila senantiasa harus dipahami secara kontekstual dalam hubungannya dengan perkembangan budaya dan perubahan-perubahan struktur sosial yang ada di masyarakat (Kusuma, 1993).

Kemajuan ilmu pengetahuan dan teknologi juga turut mempengaruhi cara berpikir, bersikap dan bertindak. Perubahan struktur sosial masyarakat inilah yang mempengaruhi kesadaran hukum dan penilaian terhadap suatu tingkah laku. Apakah perbuatan tersebut dianggap lazim atau bahkan sebaliknya merupakan suatu ancaman bagi ketertiban sosial. Perbuatan yang mengancam ketertiban sosial atau kejahatan seringkali memanfaatkan atau bersaranakan teknologi. Untuk mengantisipasi perkembangan masyarakat dalam kaitannya dengan perubahan kejahatan tersebut, dapat dilakukan usaha perencanaan pembuatan hukum pidana yang menampung segala dinamika masyarakat. Hal ini 
merupakan masalah kebijakan, khususnya mengenai pemilihan sarana dalam mengatur kehidupan bermasyarakat.

Pembangunan dalam bidang hukum, khususnya pembangunan hukum pidana, tidak hanya mencakup pembangunan yang bersifat structural, yakni pembangunan lembaga-lembaga hukum yang bergerak dalam suatu mekanisme, tetapi juga harus mencakup pembangunan substansi berupa produkproduk yang merupakan hasil sistem hukum dalam bentuk peraturan pidana dan yang bersifat kultural, yakni sikap-sikap dan nilai-nilai yang mempengaruhi berlakunya sistem hukum (Jaya, 2005).

Hukum pidana seringkali digunakan dalam menyelesaikan masalah sosial terutama dalam penanggulangan kejahatan, khususnya masalah kejahatan pedofilia sebagai salah satu bentuk penyakit masyarakat, satu bentuk patologi sosial (Kartono, 2005). Penegak hukum pidana untuk menanggulangi pedofilia sebagai perilaku yang menyimpang harus terus dilakukan. Hal ini sangat beralasan karena pedofilia merupakan ancaman yang nyata terhadap norma-norma sosial yang dapat menimbulkan ketegangan individual maupun ketegangan-ketegangan sosial. Pedofilia merupakan ancaman riil atau potensial bagi berlangsungnya ketertiban sosial (Sadli, 1998).

Menurut Nawawi, sekiranya dalam kebijakan penanggulangan kejahatan (pedofilia) digunakan upaya/sarana hukum pidana (penal), sehingga kebijakan hukum pidana harus diarahkan pada tujuan dari kebijakan sosial (social policy) yang terdiri dari kebijakan atau upaya-upaya untuk kesejahteraan sosial (social welfare policy) (Nawawi, 2001). Oleh karena itu dapat dikatakan bahwa tujuan akhir dari tujuan utama politik kriminal ialah perlindungan masyarakat untuk mencapai kesejahteraan.

Tindak pidana pedofilia secara eksplisit memang tidak diatur dalam hukum Indonesia tetapi tentang arti pedofilia sendiri harus di pahami, yang mana melakukan tindak pidana pelecehan seksual terhadap anak di bawah umur, dan anak itu sendiri dilindungi dari tindakan eksploitasi seksual yang terdapat dalam KUHP itu sendiri.

Pemerintah telah berupaya memberikan perlindungan hukum pada anak sehingga anak dapat memperoleh jaminan atas kelangsungan hidup dan penghidupannya sebagai bagian dari hak asasi manusia. Berdasarkan Pasal 20 Undang-Undang Nomor 35 Tahun 2014 tentang Perlindungan Anak yang berkewajiban dalam perlindungan anak adalah Negara, Pemerintah, Pemerintah Daerah, Masyarakat, Keluarga dan Orang Tua atau Wali yang berkewajiban dan bertanggungjawab dalam menyelenggarakan perlindungan terhadap anak.

\section{Sanksi Pidana bagi Pelaku Tindak Pidana Pedofilia terhadap Anak}

Berikut ini meliputi pengaturan tindak pidana pedofilia yang dapat digunakan untuk menjerat pelaku pelecehan seksual pada anak termasuk para pedofilia di Indonesia berdasarkan Hukum Pidana Indonesia:

\section{a. Dalam Kitab Undang-Undang Hukum Pidana (KUHP)}

\section{1) Pasal 29 KUHP}

"Barang siapa dengan kekerasan atau ancaman kekerasan memaksa seseorang untuk melakukan atau membiarkan dilakukannya perbuatan cabul, diancam karena melakukan perbuatan yang menyerang kehormatan, kesusilaam, dendam pidana penjara paling lama Sembilan tahun".

2) Pasal 290 ayat (2) KUHP

"Diancam dengan pidana penjara paling lama tujuh tahun; barang siapa melakukan perbuatan cabul dengan seseorang padahal diketahuinya atau sepatuhnya harus diduganya bahwa umumnya belum lima belas tahun atau kalau umumnya tidak jelas, bahwa yang bersangkutan belum masanya untuk dikawini."

\section{3) Pasal 290 ayat (3) KUHP}

"Diancam dengan pidana penjara paling lama tujuh tahun: "Barang siapa membujuk (menggoda) seseorang yang diketahuinya atau patut harus disangkanya bahwa umur orang itu belum cukup lima belas tahun atau kalau tidak nyata berapa umurnya, bahwa ia belum mampu dikawini, untuk melakukan atau membiarkan perbuatan cabul atau bersetubuh di luar perkawinan dengan orang lain."

\section{4) Pasal 292 KUHP}

"Orang dewasa yang melakukan perbuatan cabul dengan orang lain sesama kelamin, yang diketahuinya atau sepatutnya harus diduganya belum dewasa, diancam pidana penjara paling lama lima tahun."

5) Pasal 293 ayat (1) KUHP 
"Barang siapa dengan memberi atau menjanjikan uang atau barang, dengan menyalahgunakan perbawa yang timbul dari hubungan keadaan, atau dengan penyesatan sengaja menggerakkan seorang belum dewasa dan baik tingkah lakunya untuk melakukan atau membiarkan dilakukannya perbuatan cabul dengan dia, padahal belum cukup umurnya atau selayaknya diduganya belum cukup umur, diancam dengan pidana penjara paling lama lima tahun.”

6) Pasal 294 ayat (1) KUHP

"Barang siapa melakukan perbuatan cabul dengan anaknya, anak tirinya, anak angkatnya, anak di bawah pengawasannya yang belum dewasa, yang pemeliharanya, pendidikan atau penjagaannya diserahkan kepada ataupun dengan bujangnya atau bawahannya yang belum dewasa, diancam dengan pidana penjara paling lama tujuh tahun."

b. Undang-Undang Nomor 35 Tahun 2014 tentang Perubahan Undang-Undang Nomor 23 Tahun 2002 tentang Perlindungan Anak

Pasal 15 Undang-Undang Nomor 35 Tahun 2014 tentang Perubahan Undang-Undang Nomor 23 Tahun 2002 tentang Perlindungan Anak menyatakan: "Setiap anak berhak untuk memperoleh perlindungan dari:

1) Penyalahgunaan dalam kegiatan politik;

2) Pelibatan dalam sengketa bersenjata;

3) Pelibatan dalam kerusuhan sosial;

4) Pelibatan dalam peristiwa yang mengandung unsur kekerasan;

5) Pelibatan dalam peperangan; dan

6) Kejahatan seksual.

Pasal 82:

1) Setiap orang yang melanggar ketentuan sebagaiamana dimaksud dalam pasal $76 \mathrm{E}$ dipidana dengan pidana penjara paling singkat 5 (lima) tahun dan paling lama 15 (lima belas) tahun dan denda paling banyak Rp. 5.000.000.000,- (Lima Milyar Rupiah).

2) Dalam hal tindak pidana sebagaimana dimaksud pada ayat (1) dilakukan oleh Orang Tua, Wali, Pengasuh Anak, Pendidik, atau Tenaga Kependidikan, maka pidananya ditambah 1/3 (sepertiga) dari ancaman pidana sebagaimana dimaksud pada ayat (1).

\section{SIMPULAN DAN SARAN}

\section{Simpulan}

Dari deskripsi hasil penelitian yang diuraikan di atas, juga dari rumusan masalah yang dirumuskan, dapat ditarik simpulan di bawah ini:

a. Pengaturan tindak pidana pedofilia terhadap anak yang digunakan untuk menjerat pelaku pelecehan seksual pada anak, termasuk para pedofilia, di Indonesia berdasarkan Hukum Pidana Indonesia adalah Kitab Undang-Undang Hukum Pidana, dan UU Nomor 35 Tahun 2014 tentang Perubahan UU Nomor 23 Tahun 2002 tentang Perlindungan Anak.

b. Sanksi pidana bagi pelaku tindak pidana pedofilia terhadap anak diatur dalam Undang-Undang Nomor 23 Tahun 2002 tentang Perlindungan Anak yang menjelaskan bahwa perbuatan memaksa kehendak orang dewasa terhadap anak di bawah umur yang dilakukan tanpa atau dengan kekerasan dijerat dengan hukuman antara 3 (tiga) sampai 10 (sepuluh) tahun penjara. Selain itu, dalam Kitab Undang-Undang Hukum Pidana perbuatan tersebut diancam dengan hukuman maksimal 15 (Lima Belas) tahun penjara.

\section{Saran}

Setelah memberikan simpulan, penulis mengajukan saran sebagai berikut:

a. Para penegak hukum diharapkan memberikan keadilan dengan seadil-adilnya tanpa adanya ketimpangan hukum terhadap korban, keluarga korban maupun pelaku. Seperti halnya kejahatan seksual terhadap anak di bawah umur yang banyak terjadi pada masyarakat kita. Penegak hukum di Indonesia belum sampai membuat rasa jera bagi pelaku kejahatan.

b. Sudah seharusnya pemerintah memberikan ketegasan hukum bagi pelaku kejahatan seksual terhadap anak di bawah umur karena perbuatan ini tidak hanya meresahkan seseorang sebagai korban saja tetapi keluarga dan juga masyarakat di sekitarnya. 


\section{DAFTAR PUSTAKA}

Arief, B. N. (2002). Bunga Rampai Kebijakan Hukum Pidana dan Sari Kuliah Perbandingan Hukum Pidana.

Balai Pustaka Sosial RI. (2002). Anak yang Membutuhkan Perlindungan Khusus. P3KS Press.

Depsos, R. (2002). Anak yang Membutuhkan Perlindungan Khusus.

Irianto, K. (2010). Memahami Seksologi. Sinar Baru Algesindo.

Jaya, N. S. P. (2005). Relevansi Hukum Pidana dalam Pembaharuan Hukum Pidana Nasional. PT. Citra Aditya Bakti.

Kartonegero. (2012). Diktat Kuliah Hukum Pidana. Balai Lektur Mahasiswa.

Kartono, K. (2005). Patologi Sosial (I). PT. Raja Grafindo Persada.

Kusuma, M. W. (1993). Tindak Pidana Kesusilaan (Perzinaan dan Pemerkosaan) dalam Rancangan KUHP. Soegijapranata.

Marpaung, L. (1996). Kejahatan terhadap Delik Kesusilaan dan Masalah Prevensinya. Sinar Grafika.

Nawawi, B. (2001). Masalah Penegakan Hukum dan Kebijakan Penanggulangan Kejahatan. PT. Citra Aditya Bakti.

Poerwadarminta, W. (2002). Kamus Besar Bahasa Indonesia. Balai Pustaka.

Prodjodikoro, W. (1989). Wirjono Prodjodikoro. PT Eresco.

Sa'abah, M. U. (1997). Seks dan Kita. Gema Insani Press.

Sadarjoen, S. S. (2005). Bunga Rampai Kasus Gangguan Psikoseksual. Rfika Aditama.

Sadli, S. (1998). Teori-Teori dan Kebijakan Pidana Cetakan II. Penerbit Alumni.

Sholeh, S. (2001). Dasar Hukum Perlindungan Anak. CV. Navindo Pustaka Mandiri.

Suma, M. A. (2001). Pidana Islam di Indonesia Peluang Prospek, dan Tantangan. Pustaka Firdaus.

Tongat, R. S. dalam. (2003). Hukum Pidana Materiil Tinjauan atas Tindak Pidana Terhadap Subyek Hukum Dalam KUHP. Djambatan. 